\title{
Results of Rearing Broiler Chickens Under Various Systems
}

\author{
Joanna Kuźniacka ${ }^{1}$, Marek Adamski ${ }^{1}$, Rafał Czarnecki ${ }^{1} \&$ Mirosław Banaszak ${ }^{1}$ \\ ${ }^{1}$ Department of Poultry Breeding and Animal Material Evaluation, Faculty of Animal Breeding and Biology, \\ University of Technology and Life Sciences, Bydgoszcz, Poland \\ Correspondence: Marek Adamski, Department of Poultry Breeding and Animal Material Evaluation, Faculty of \\ Animal Breeding and Biology, University of Technology and Life Sciences, Bydgoszcz, Poland. E-mail: \\ adamski@utp.edu.pl
}

\author{
Received: December 16, 2013 Accepted: January 17, 2014 Online Published: March 15, 2014 \\ doi:10.5539/jas.v6n4p19 URL: http://dx.doi.org/10.5539/jas.v6n4p19
}

\begin{abstract}
The aim of the study was comparison of the results of rearing broilers kept under intensive and semi-intensive systems, fed with complete feeds with an addition of various proportions of wheat grain. The study was carried out on 100 broilers, HUBBARD - FLEX, of both sexes. The birds were reared up to 42 days of age in an intensive system (group I), as well as in a semi-intensive system (group II). In the 5th week of rearing, in the nutrition of group II, $30 \%$ of complete feed was replaced with wheat grain, increasing its proportion in the dose up to $50 \%$ in the last week of rearing. System of keeping broilers did not affect significantly their bodyweight at the end of rearing, as well as their meat yield and muscle content in carcasses. Chicken fed with complete feeds, kept under an intensive system were distinguished by higher fattiness expressed as an abdominal fat weight, as well as by lower average intake of feed mixtures per individual broiler.
\end{abstract}

Keywords: broilers, rearing system, carcass composition, meat quality

\section{Introduction}

Broiler chickens should be characterized by good dressing percentage, desired structure, taking into consideration as high as possible proportion of meat per carcass, optimum distribution of fat tissue as well as proper skin color. With reference to this, proportions of main carcass parts (breasts, thighs and drumsticks), as well as presence of particular tissues in them, are considered to be significant parameters defining broiler meat quality (Lewis et al., 1997; Suto et al., 1998; Holcman et al., 2003; Ristic, 2003). The above mentioned quality traits depend on many biological factors, among others, on the genotype, sex and age (Lewis et al., 1997; Bokkers \& Koene, 2003; Hellmeister et al., 2003; Sogunle et al., 2010). Among numerous non-genetic factors, the most important role plays broiler nutrition. Raw materials used in the feed mixture, their characteristic chemical composition, protein and mineral elements content and energy value of formulated doses, affect chemical composition of the muscle tissue (Shahin \& Abd Elazeem, 2005, 2006; Łukasiewicz, 2012, Sirirat et al., 2012). In recent years many authors have also paid attention to the rearing of broilers, as a particularly important factor influencing quality traits of meat (Castelini, 2005, Ponte, 2008, Meluzzi et al., 2009, Bogosavljević-Bošković et al., 2012; Nawalny, 2012).

In an intensive broiler chicken rearing, a quickly growing material is used as well as complete feeds. However, when rearing broiler chickens under a semi-intensive or an extensive system, part of the complete feeds is replaced with cereal grains. The use of complete feeds throughout the whole rearing period in broiler chickens under a semi-intensive and an extensive system may increase the costs of chicken nutrition twice throughout the whole production cycle (Krawczyk \& Wężyk, 2002). Therefore, numerous studies have been undertaken (Langhouta et al., 1993; Dov et al., 1998; Gill et al., 1998, Krawczyk et al., 2002) to establish optimum doses of cereal, mainly of wheat, for complete feeds used in broiler chicken rearing. Results of the presented studies are consistent. Krawczyk et al. (2002) found a possibility of replacing up to $30 \%$ of the feed with wheat grain without an effect on the production results in chickens. However, Dov et al. (1998) determined addition of this grain on the level of $25 \%$.

Due to the increasing interest in rearing chicken under semi-intensive and extensive systems (Fanatico et al., 2006; Pavlovski et al., 2009; Bancos, 2010), as well as to the possibility of decreasing production costs and using available on the market commercial line chickens, it is justifiable to undertake research in this area. 
The aim of the study was comparison of the results of rearing broiler chickens under an intensive and semi-intensive system fed with complete feeds with the addition of various proportions of wheat grain.

\section{Method}

\subsection{Experimental Animal}

The study material included 100 broiler chickens, Hubbard-Flex. Chickens were compared in two experimental groups ( 50 chickens in each one) and further divided into 5 sub-groups (each group - 10 chickens). Chickens from the first experimental group (I) throughout the whole 42-day rearing were kept in a room without access to free-run under regulated environmental conditions in accordance with recommendations (Hubbard-Flex Broiler Management Guide, 2010). Whereas chickens from the other experimental group (II) from their 4th week of rearing had access to restricted sandy free range and remained under the effect of the conditions of natural environment. Chickens in both groups were fed ad libitum, from the 1st to 2 nd week with a mixture richer in protein $(21.5 \%)$, from the 3 rd week to the $5^{\text {th }}$ week with a mixture lower in protein $(18 \%)$. In the last week of rearing, protein in the mixture fed to the chickens constituted $17.5 \%$. Mixtures in the whole period of rearing contained from 2,950 to 3,000 kcal (12.34 to $12.55 \mathrm{MJ}$ ) of metabolic energy per kilogram. Chemical composition of mixtures for chickens was in accordance with recommendations (Smulikowska \& Rutkowski, 2005). In the 5th week of rearing, $30 \%$ of the complete feed was replaced with wheat grains in the nutrition of the second experimental group. In the last week of rearing, proportion of wheat per dose was $50 \%$. From the 3 rd week of rearing both experimental groups of chickens had polfamix $\mathrm{AZ}$ added to their water.

\subsection{Data collection and Analysis}

The broiler chickens were weighed individually on the first day and in the $1 \mathrm{st}$, 2nd, $3 \mathrm{rd}$, 4th, $5^{\text {th }}$, and 6 th week of rearing with an accuracy within 5 grams. During the rearing period, the amount of given feed as well as leftovers were recorded in subgroups. This allowed for calculation of the feed intake and its usage per broiler and per one kilogram of bodyweight. Moreover, the European Broiler Index was calulated. In the 6th week of life birds were slaughtered in abattoir. After slaughtering and plucking non eviscerated carcasses were weighed followed by the dissection of the entire carcasses according to the method described by Ziołecki and Doruchowski (1989).

Collected numerical data was statistically elaborated calculating mean values (x) and standard deviation (SD) of all the studied traits. Obtained data was subjected to analysis of variance and evaluation of significance of differences between groups with the use of Scheffe's method.

\section{Results and Discussion}

\subsection{The Effect of Housing System on Feed Intake}

Analyzing mean values of feed mixture intake per one broiler it was proved that broiler chickens under a semi-intensive system (group II $-4.62 \mathrm{~kg}$ ) were characterized by a higher mixture intake by $160 \mathrm{~g}$, compared with chickens under an intensive system (group I $-4.46 \mathrm{~kg}$ ). This was probably connected with the replacement of 30 and $50 \%$ of daily dose of complete feed with wheat grain, and with moving chickens onto free-range, and thus decreasing stocking density per $1 \mathrm{~m}^{2}$.

Similarly, slightly higher (by $90 \mathrm{~g}$ ) feed mixture intake was observed per $1 \mathrm{~kg}$ of bodyweight gain in chickens from group II $(1.85 \mathrm{~kg})$ compared with chickens from group I $(1.76 \mathrm{~kg})$. Skomorucha et al. (2011) in their conducted research confirmed that in case of Hubbard-Flex broiler chickens, rearing system affects feed utilization. Dou et al. (2009) carried out a research on slowly-growing Gusbi chickens housing them under two systems. More favorable feed conversion ratio of 3.95 (compared to 4.41) was confirmed in chickens housed under an intensive system. Also Lima and Naas (2005) proved significant differences in the feed conversion ratio (2.98 vs 1.97) between chickens housed with and without access to the free-range.

\subsection{The Effect of Housing System on Body Weight}

The effect of the housing system on the final bodyweight was widely studied by many authors, most of whom suggest that free-range chickens obtain a lower bodyweight compared with chickens housed indoors (Castelini et al., 2002; Filho et al., 2003; Buchanan et al., 2007). However, it seems that the main factor influencing broiler's bodyweight is genotype, independently of the used production system (Castelini et al., 2008; Sirri et al., 2010). In the authors' own research, broiler chickens at the end of rearing weighed (Table 1) on average 2,530 g (group I) and 2,494 $\mathrm{g}$ (group II). Lack of statistically significant differences was observed in the bodyweight between males and females, as well as between evaluated groups up to the 5 th week of rearing. In the $6^{\text {th }}$ week in both groups, visible sexual dimorphism was proved which was expressed statistically with a significantly higher bodyweight of roosters compared with hens. Chickens under an intensive and semi-intensive system obtained a satisfactory 
European Broiler Index (EBI). Lower EBI (320 points) in chickens from group II resulted from a higher feed utilization and a lower bodyweight compared with chickens from group I (338 points).

Table 1. Bodyweight of broiler chickens in the period of rearing

\begin{tabular}{|c|c|c|c|c|c|c|c|}
\hline \multirow{2}{*}{ Group } & \multirow{2}{*}{ Sex } & \multicolumn{6}{|c|}{ Weeks of age - trait value } \\
\hline & & 1 & 2 & 3 & 4 & 5 & 6 \\
\hline \multirow{3}{*}{ I } & $\hat{0}$ & $167 \pm 26$ & $458 \pm 39$ & $918 \pm 88$ & $1559 \pm 148$ & $2113 \pm 310$ & $2722 \pm 268$ \\
\hline & q & $164 \pm 12$ & $417 \pm 35$ & $823 \pm 69$ & $1325 \pm 108$ & $1843 \pm 158$ & $2332 \pm 215$ \\
\hline & $\widehat{0}+q$ & $165 \pm 21$ & $440 \pm 42$ & $868 \pm 99$ & $1450 \pm 184$ & $1978 \pm 299$ & $2530 * \pm 328$ \\
\hline \multirow{3}{*}{ II } & $\hat{0}$ & $175 \pm 15$ & $435 \pm 41$ & $876 \pm 107$ & $1464 \pm 137$ & $2061 \pm 241$ & $2687 \pm 286$ \\
\hline & q & $168 \pm 12$ & $419 \pm 35$ & $804 \pm 71$ & $1311 \pm 122$ & $1806 \pm 174$ & $2284 \pm 214$ \\
\hline & సᄁo & $171 \pm 14$ & $426 \pm 39$ & $847 \pm 91$ & $1388 \pm 139$ & $1942 \pm 225$ & $2494 * \pm 305$ \\
\hline
\end{tabular}

* - significant differences were determined statistically between sexes within groups ( $\mathrm{P} \leq 0.05)$; Mean $\pm \mathrm{SD}$.

\subsection{The Effect of Housing System on Slaughter Traits}

Bodyweight before slaughter as well as the weight of carcass eviscerated with neck in chickens selected for dissection (Table 2) did not significantly differ statistically between the groups. This testifies to the lack of effect of the housing system, and of introducing wholegrain wheat into the daily dose, on these traits. In the evaluated groups, statistically, significantly higher bodyweight and carcass weight was observed in males compared with females. Dressing percentage in chickens under different systems was also similar and was on average $73.8 \%$ (group I) and $73.9 \%$ (group II). However, statistically significantly higher bodyweight was proved in carcass remainders in broilers under an intensive system compared with chickens in a semi-intensive system. Research carried out by Bogosavljević-Bošković et al. (2011) did not indicate any significant effect of rearing system on dressing percentage in broilers Cobb 500. These results are in accordance with the data of Poltowicz \& Doktor (2011), who found that free-range chickens Ross 308 , had only $0.64 \%$ higher dressing percentage compared with broilers housed indoors. On the other hand, Skomorucha et al. (2008), determined a higher proportional dressing percentage in 42-day-old broilers Cobb housed without access to free-range. Dou et al. (2009) also while comparing dressing percentage in broilers under both systems obtained results $69.90 \%$ to $69.88 \%$ in favor of an intensive rearing.

Table 2. Bodyweight, carcass weight, dressing percentage and parts of broiler chicken carcass

\begin{tabular}{|c|c|c|c|c|c|c|c|c|c|c|c|}
\hline \multirow{3}{*}{ Group } & \multirow{3}{*}{ Sex } & & \multicolumn{2}{|c|}{ Weight (g) } & \multirow{3}{*}{$\begin{array}{l}\text { Dressing } \\
\text { percentage } \\
(\%)\end{array}$} & \multicolumn{6}{|c|}{ Weight per eviscerated carcass with neck } \\
\hline & & & \multirow{2}{*}{$\begin{array}{l}\text { Broiler } \\
\text { body } \\
\text { before } \\
\text { slaughter }\end{array}$} & \multirow{2}{*}{$\begin{array}{l}\text { Carcass } \\
\text { eviscerated } \\
\text { with neck }\end{array}$} & & \multicolumn{2}{|c|}{ Wings } & \multicolumn{2}{|c|}{ Neck } & \multirow{2}{*}{$\begin{array}{l}\text { Giblets } \\
\text { (g) }\end{array}$} & \multirow{2}{*}{$\begin{array}{l}\text { Carcass } \\
\text { remainders } \\
(\mathrm{g})\end{array}$} \\
\hline & & & & & & g & $\%$ & $\mathrm{~g}$ & $\%$ & & \\
\hline \multirow{6}{*}{ I } & \multirow{2}{*}{ त } & $\mathrm{x}$ & 2838 & 2096 & 73.8 & 199 & 9.5 & 67 & 3.2 & 110 & $516^{a}$ \\
\hline & & $\mathrm{S}_{\mathrm{x}}$ & 130.8 & 161 & 2.9 & 15.4 & 0.7 & 8.8 & 0.4 & 12.6 & 72.6 \\
\hline & \multirow{2}{*}{ q } & $\mathrm{x}$ & 2328 & 1718 & 73.8 & 170 & 10 & 64.2 & 3.7 & $86^{*}$ & 369 \\
\hline & & $\mathrm{S}_{\mathrm{x}}$ & 65.4 & 63 & 1.2 & 18,2 & 1.2 & 15.9 & 0.8 & 13.1 & 58.5 \\
\hline & \multirow{2}{*}{$\partial^{\top}+t$} & $\mathrm{x}$ & $2583^{*}$ & $1907 *$ & 73.8 & $184^{*}$ & 9.7 & 66 & 3.5 & 98 & $442^{\mathrm{a} *}$ \\
\hline & & $\mathrm{S}_{\mathrm{x}}$ & 281.7 & 228 & 2.1 & 22.2 & 0.9 & 12.5 & 0.7 & 17.7 & 99.0 \\
\hline \multirow{6}{*}{ II } & \multirow{2}{*}{$\sigma^{\lambda}$} & $\mathrm{x}$ & 2724 & 2007 & 73.7 & 189 & 9.4 & 66 & 3.3 & 102 & $465^{\circ}$ \\
\hline & & $\mathrm{S}_{\mathrm{x}}$ & 65.9 & 56.1 & 1.0 & 11.9 & 0.5 & 8.4 & 0.4 & 12.9 & 35.8 \\
\hline & \multirow{2}{*}{ 우 } & $\mathrm{x}$ & 2269 & 1681 & 74.1 & 161 & 9.6 & 56 & 3.3 & 89 & 380 \\
\hline & & $\mathrm{S}_{\mathrm{x}}$ & 57.1 & 50.8 & 0.7 & 9.4 & 0.6 & 10 & 0.7 & 12.2 & 40.3 \\
\hline & \multirow{2}{*}{ ऽ우 } & $\mathrm{x}$ & $2496^{*}$ & $1844 *$ & 73.9 & $175^{*}$ & 9.5 & 61 & 3.3 & 96 & $422^{\mathrm{b} *}$ \\
\hline & & $\mathrm{S}_{\mathrm{x}}$ & 242.4 & 176 & 0.9 & 17.8 & 0.6 & 10.4 & 0.5 & 13.9 & 57.3 \\
\hline
\end{tabular}

$\mathrm{a}, \mathrm{b}$ - mean values denoted by different letters within a sex group statistically differ significantly between groups.

*- significant differences were determined statistically between sexes within groups. 


\subsection{The Effect of Housing System on Muscle Content and Fattiness}

Housing system and introducing wholegrain wheat into daily feed dose did not affect the total muscle content and fattiness of the evaluated broiler chickens (Table 3). Chickens in both experimental groups were characterized by the same proportion of breast muscles (28.0) per carcass as well as similar proportion of muscles in legs and muscles in total. In both groups, statistically, significantly higher muscle weight in breasts, legs and in total was observed in males compared with females. Many authors give different information concerning the effect of the housing system on the proportion of particular parts in carcass. Bogosavljević-Bošković et al. $(2010 ; 2011)$ did not prove any effect of the free-range system on the proportion of particular parts of carcass, including breasts, thighs and drumsticks, compared with broilers housed indoors, although different commercial hybrids were used in the two experiments (Hydro G and Cobb500). Similar results were obtained by Santos et al. (2008). However, Dou et al. (2009) as well as Castelini et al. (2002), report that chickens under a free-range system are characterized by a higher proportion of breasts and thighs. Lei \& Van Beek (1997) suggest that an increased proportion, especially in leg muscles, is connected with an increased motor activity in chickens. On the other hand, Poltowicz \& Doktor (2011), noted a higher proportion of breasts, thighs and drumsticks in chickens Ross 308 under a conventional indoor housing compared with free-range broilers $(\mathrm{P}>0.05)$.

Table 3. Comparison of muscle content and fattiness in broiler chickens

\begin{tabular}{|c|c|c|c|c|c|c|c|c|c|c|c|c|c|c|}
\hline \multirow{4}{*}{ Group } & \multirow{4}{*}{ Sex } & & \multicolumn{12}{|c|}{ Weight and proportion in eviscerated carcass with neck } \\
\hline & & & \multicolumn{6}{|c|}{ muscles } & \multirow{2}{*}{\multicolumn{2}{|c|}{ skin with subcutaneous fat }} & \multirow{2}{*}{\multicolumn{2}{|c|}{ abdominal fat }} & \multirow{2}{*}{\multicolumn{2}{|c|}{ total fatness }} \\
\hline & & & \multicolumn{2}{|c|}{ breast } & \multicolumn{2}{|c|}{ legs } & \multicolumn{2}{|c|}{ total } & & & & & & \\
\hline & & & $\mathrm{g}$ & $\%$ & $\mathrm{~g}$ & $\%$ & g & $\%$ & $\mathrm{~g}$ & $\%$ & $\mathrm{~g}$ & $\%$ & $\mathrm{~g}$ & $\%$ \\
\hline \multirow{6}{*}{ I } & \multirow{2}{*}{ 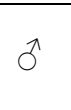 } & $\mathrm{x}$ & 577 & 27.6 & 441 & 21 & 1018 & 48.6 & 196 & 11.4 & $49.0^{\mathrm{a}}$ & 2.4 & 247 & 11.8 \\
\hline & & $\mathrm{S}_{\mathrm{x}}$ & 65.5 & 2.4 & 39.6 & 0.8 & 87.5 & 1.8 & 20.4 & 1.8 & 14.1 & 0.6 & 18 & 0.5 \\
\hline & \multirow{2}{*}{ 우 } & $\mathrm{x}$ & 481 & 28 & 344 & 20 & 825 & 48 & 194 & 11.3 & 42 & 2.4 & 248 & 14.5 \\
\hline & & $\mathrm{S}_{\mathrm{x}}$ & 38.7 & 1.9 & 22.1 & 1.1 & 55.1 & 2.6 & 53.4 & 3.1 & 20.3 & 1.2 & 66 & 3.9 \\
\hline & \multirow{2}{*}{$\partial^{\top}+q$} & $\mathrm{x}$ & $529^{*}$ & 28 & $392 *$ & 20.5 & $921 *$ & 48.2 & 195 & 10.3 & $45.0^{\mathrm{a}}$ & 2.4 & 248 & 13 \\
\hline & & $S_{x}$ & 72 & 2.1 & 59 & 1.1 & 122.1 & 2.2 & 39.1 & 2.4 & 17.3 & 0.9 & 47 & 3 \\
\hline \multirow{6}{*}{ II } & \multirow{2}{*}{$0^{\lambda}$} & $\mathrm{x}$ & 588 & 29.3 & 415 & 20.7 & 1003 & 50 & 193 & 9.6 & $30.0^{b}$ & 1.5 & 253 & 12.6 \\
\hline & & $\mathrm{S}_{\mathrm{x}}$ & 41.3 & 1.5 & 35 & 1.5 & 67.7 & 2.5 & 29 & 1.4 & 11.1 & 0.6 & 36 & 1.7 \\
\hline & \multirow{2}{*}{ 오 } & $\mathrm{x}$ & 456 & 27 & 346 & 20.5 & 802 & 47.7 & 192 & 9.3 & 38 & 2.3 & 244 & 14.5 \\
\hline & & $\mathrm{S}_{\mathrm{x}}$ & 48 & 2.8 & 26.2 & 1.1 & 66.4 & 3.4 & 32 & 0.9 & 24.8 & 1.6 & 31.4 & 1.8 \\
\hline & \multirow{2}{*}{ ठ우 } & $\mathrm{x}$ & $522 *$ & 28 & $381^{*}$ & 20.6 & $903^{*}$ & 49 & 192 & 10.5 & $34.0^{\mathrm{b}}$ & 1.9 & 248 & 13.5 \\
\hline & & $S_{x}$ & 80.5 & 2.1 & 47 & 1.3 & 122.3 & 3.1 & 29.4 & 1.8 & 19 & 1.2 & 33 & 2 \\
\hline
\end{tabular}

$\mathrm{a}, \mathrm{b}$ - mean values denoted by different letters within a sex group statistically differ significantly between groups.

*- significant differences were determined statistically between sexes within groups.

In the authors' own research lack of statistically significant differences was observed in the weight and proportion of skin with subcutaneous fat between the evaluated groups and sexes. However, broiler chickens under a semi-intensive system were characterized by statistically significantly lower weight of abdominal fat deposition compared with chickens under an intensive system. Lower content of abdominal fat deposition was potentially caused by an increased motor activity in chickens (Lewis et al., 1997; Castelini et al., 2002; Dou et al., 2009). This is confirmed by the research carried out by Bogosavljević-Bošković et al. (2006) on broilers Hybro G, in which proportion of abdominal fat deposition was respectively: $1.88 \%$ in free-range chickens and $1.98 \%$ in those under an intensive indoor system. Dou et al. (2009) noted 3.0\% abdominal fat deposition in free-range broilers and up to $6.5 \%$ in those housed indoors. However, Castelini et al. (2002) proved the difference of $0.9 \%$ vs $1.9 \%$ after 56 days and $1 \%$ compared with $2.9 \%$ at 81 days of ecological rearing of broilers Ross, confirming significantly lower fattiness compared with the conventional rearing. 


\section{Conclusion}

The chickens kept with access to runs (semi-intensive system) characterized by higher intake of feed with 30 and $50 \%$ content of wheat grain compared with chickens reared under an intensive system (in door). Broiler chickens fed with complete feeds, kept under an intensive system distinguished by a higher proportion of abdominal fat deposition compared with chickens kept with access to runs. Body weight at the end of rearing, dressing percentage and carcass muscle content in broiler chickens of the same origin kept under both systems were similar.

\section{References}

Bancos, C. (2010). Research on some hygienic factors influence on broiler health, productivity and meat quality. $\mathrm{Ph}$. D. Thesis. University of Agricultural Sciences and Veterinary Medicine Cluj-Napoca.

Bogosavljević-Bošković, S., Kurćubić, V., Petrović, M. D., \& Radović, V. (2006). The Effect of Sex and Rearing System on Carcass Composition and Cut Yields of Broiler Chickens. Czech J. Anim. Sci., 51, 31-38.

Bogosavljević-Bošković, S., Mitrović, S., Djoković, R., Dosković, V., \& Djermanović, V. (2010). Chemical composition of chicken meat produced in extensive indoor and free-range systems. Afr J Biotechnol, 53, 9069-9075.

Bogosavljević-Bošković, S., Pavlovski, Z., Petrović, M., Dosković, V., \& Rakonjac, S. (2011). The effect of rearing system and length of fattening period on selected parameters of broiler meat quality. Arch. Geflügelk., $75,158-163$.

Bogosavljević-Bošković, S., Rakonjac, S., Dosković, V., \& Petrović, M. D. (2012). Broiler rearing system: a review of major fattening results and meat quality traits. World Poultry Sci. J., 68, 217-228. http://dx.doi.org/10.1017/S004393391200027X

Bokkers, E. A. M., \& Koene, P. (2003). Behaviour of fast- and slow growing broilers to 12 weeks of age and the $\begin{array}{lllll}\text { physical Apl. Anim. } & \text { Behav. }\end{array}$ http://dx.doi.org/10.1016/S0168-1591(02)00251-4

Buchanan, N. P., Hott, J. M., Kimbler, L. B., \& Moritz, J. S. (2007). Nutrient composition and digestibility of organic broiler diets and pasture forages. J. Appl. Poult. Res., 16, 13-21.

Castelini, C. (2005). Organic poultry production system and meat characteristics. XVII European Symposium on the Quality of Poultry Meat, Doorwerth.

Castelini, C., Berri, C., Le Bihan Duval, E., \& Martino, G. (2008). Qualitative attributes and consumer perception of organic and free-range poultry meat. World Poultry Sci. J., 64, 500-512. http://dx.doi.org/10.1017/S0043933908000172

Castelini, C., Mugnai, C., \& Dal Bosco, A. (2002). Effect of organic production system on broiler carcass and meat quality. Meat Sci., 60, 219-225. http://dx.doi.org/10.1016/S0309-1740(01)00124-3

Dou, T. C., Shi, S. R., Sun, H. J., \& Wang, K. H. (2009). Growth rate, carcass traits and meat quality of slow-growing chicken grown according to three raising systems. Anim. Sci. Pap. Rep., 27, 361-369.

Dov, C., Rimsky, I., Dvorin, A., Makovsky, B., Gur, N., Ptichi, I., .. Asaf Fishbein. (1998). The effect of feeding whole wheat. The Worlds Poultry Science Association, Israel Branch, The 36th annual convention 1998 (pp. 16-17).

Fanatico, A. C., Pillai, P. B., Cavit, L. C., Melluent, J. F., Emmert, J. L., \& Owens, C. M. (2006). Evaluation of slower growing genotypes grown with and without outdoor access: sensory attributes. Poult Sci., 85, 337-343. http://dx.doi.org/10.1093/ps/85.2.337

Filho, P. H., Menten, J. F. M., Neves da Silva, M. A., Coelho, A. A. D., \& Savino, V. J. M. (2003). Effect of genotype and rearing system on performance of alternative lines of broiler chickens. R. Bras. Zootec., 32, 1883-1889.

Fortomaris, P., Arsenos, G., Tserveni-Gousi, A., \& Yannakopoulos, A. (2007). Performance and behaviour of broiler chickens as affected by the housing system. Arch. Geflügelk., 71, 97-104.

Gill, C., Viola, S., Rand, N., Noy, Y., Dvorin, A., Litman, M., ... Mastbaum, Y. (1998). Effect of feeding programs and addition of whole grains on broiler performances. The Worlds Poultry Science Association, Israel Branch, The $36^{\text {th }}$ annual convention 1998 (pp. 20-22). 
Hellmeister, F, Machadomenten, J. F., Neves Da Silva, M. A., Coelho, A. A. D., \& Savino, V. J. M. (2003). Efeito de Genótipo e do Sistema de Criacâo sobre o Desempenho de frangos Tipo Caipira. R. Bras. Zootec, 32(6), 1883-1889. http://dx.doi.org/10.1590/S1516-35982003000800012

Holcman, A., Vadnjal, R., Žlender, B., \& Stibilj, V. (2003). Chemical composition of chicken meat from free-range and extensive indoor rearing. Arch. Geflügelk, 67(3), 120-124.

Krawczyk, J., \& Wężyk, S. (2002). Wpływ długości czasu odchowu i genotypu na ekonomiczną efektywność produkcji kurcząt brojlerów. Rocz. Nauk. Zoot., 29(1), 319-328.

Krawczyk, J., Cywa-Benko, K., \& Wężyk, S. (2002). Efekt stosowania ziarna pszenicy w żywieniu kurcząt brojlerów (in Polish). Rocz. Nauk. Zoot., 16(Suppl.), 229-234.

Lei, S., \& Van Peek, G. (1997). Influence of activity and dietary energy on broiler performance. Carcass yield and sensory quality. Brit. Poultry Sci., 38, 183-189. http://dx.doi.org/10.1080/00071669708417966

Lewis, P. D., Perry, G. C., Farmer, L. J., \& Patterson, R. L. S. (1997). Responses of two genotypes of chicken to the diets and stocking densities typical of UK and Label Rouge production systems: I. Performance, behavior and carcass composition. Meat Sci., 45, 501-516. http://dx.doi.org/10.1016/S0309-1740(96)00084-8

Lima, A. M. C., \& Naas, I. A. (2005). Evaluating two different systems of poultry production: conventional and free-range. Braz J Poultry Sci, 7(4), 215-220

Longhout, J., Schutte, J. B., \& Perdok, H. B. (1993). Nutritional value of whole wheat in diets for broilers. World's Poultry Science Association, $9^{\text {th }}$ European Symposium on Poultry Nutrition. September 5-9, 1993 Jelenia Góra, Poland (p. 263).

Łukasiewicz, M., Pietrzak, D., Niemiec, J., Mroczek, J., \& Michalczuk, M. (2012). Application of dried distillers grains with solubles (DDGS) as a replacer of soybean meal in broiler chickens feeding. Arch. Tierz., 5, 496-505.

Meluzzi, A., Sirri, F., Castelini, C., Roncarati, A., Melloti, P., \& Franchini, A. (2009). Influence of genotype and feeding on chemical composition of organic chicken meat. Italian Journal of Animal Science, 8(2), 766-768.

Nawalny, G. (2012). The Role of Ground in the Energy Management inside a Broiler House. Journal of Agricultural Science, 4, 171-180.

Pavlovski, Z., Škrbić, Z., Lukić, M., Petrićević, V., \& Trenkovski, S. (2009). The effect of genotype and housing system on production results of fattening chickens. Biotech. Anim. Husbandry, 25, 221-229. http://dx.doi.org/10.2298/BAH0904221P

Poltowicz, K., \& Doktor, J. (2011). Effect of free-range raising on performance, carcass attributes and meat quality of broiler chickens. Anim. Sci. Pap. Rep., 29, 139-149.

Ponte, P. I. P. (2008). Effect of pasture biomass intake on growth performance and meat quality of free-range broilers. Tese de Doutoramento em Ciencia e Tecnologia Animal. Universidade Tecnica de Lisboa.

Ristic, M. (2003). Fleischqualität von broiler aus der ökologischer produktion. Biotechnol. Anim. Hysbandry, 19, 335-343.

Santos, A. I., Sakomura, N. K., Freitas, E. R., Fortes, C. M. S., \& Carrilho, E. N.V. M. (2008). Comparison of flee-range broiler chicken strain raised in confined or semi-confined systems. Braz J. Poultry Sci., 7, 85-92.

Shahin, K. A., \& Abd Elazeem, F. (2005). Effects of breed, sex and diet and their interactions on carcass composition and tissue weight distribution of broiler chickens. Arch. Tierz., 6, 612-626.

Shahin, K. A., \& Abd Elazeem, F. (2006). Effects of breed, sex and diet and their interactions on fat deposition and partitioning among depots of broiler chickens. Arch. Tierz., 2, 181-193.

Sirirat, N., Lu, J.-J., Tsung-Yu Hung, A., Chen, S.-Y., \& Lein, T.-F. (2012). Effect Different Levels of Nanoparticles Chromium Picolinate Supplementation on Growth Performance, Mineral Retention, and Immune Responses in Broiler Chickens. Journal of Agricultural Science, 4, 48-58. http://dx.doi.org/10.5539/jas.v4n12p48

Sirri, F., Castelini, C., Roncarati, A., Franchini, A., \& Meluzzi, A. (2010). Effect of feeding and genotype on the lipid profile of organic chicken meat. Eur J Lipid Sci Tech., 112, 994-1002. http://dx.doi.org/10.1002/ejlt.200900204

Skomorucha, I., \& Muchacka, R. (2007). Effect of stocking density and management system on the physiological response of broiler chickens. Ann. Anim. Sci., 7, 321-328. 
Skomorucha, I., Muchacka, R., Sosnówka-Czajka, E., \& Herbut, E. (2008). Effects of rearing with or without outdoor access and stocking density on broiler chicken productivity. Ann. Anim. Sci., 8, 387-393.

Skomorucha, I., Sosnówka-Czajka, E., \& Muchacka, R. (2011). Wpływ systemu odchowu na wyniki produkcyjne i wybrane wskaźniki stresu we krwi kurcząt brojlerów różnego pochodzenia (in Polish). Rocz. Nauk. Zoot., 38, 269-278.

Smulikowska, S., \& Rutkowski, A. (2005). Normy Żywienia Drobiu. In I. F. i Ż. Z. Zalecenia (Ed.), żywieniowe i wartość pokarmowa pasz (pp. 77-82, in Polish).

Sogunle, O. M., Egbeyale, L. T., Alajo, O. A., Adeleye, O. O., Fafiolu, A. O., Onunkwor, O. B., ... Fanimo, A. O. (2010). Comparison of meat composition and sensory values of two different strains of broiler chickens. Arch Zootec., 59, 311-314. http://dx.doi.org/10.4321/S0004-05922010000200020

Suto, Z., Horn, P., Jensen, J. F., Sorensen, P., \& Csapo, J. (1998). Carcass traits, abdominal fat deposition and chemical composition of commercial meat type chicken during twenty week growing period. Arch. Geflügelk., 62, 21-25.

Tolon, B., \& Yalcin, S. (1997). Bone characteristics and body weight of broilers in different husbandry systems. Brit. Poultry Sci., 38, 132-135. http://dx.doi.org/10.1080/00071669708417957

Ziołecki, J., \& Doruchowski, W. (1989). Metody oceny wartości rzeźnej (pp. 1-22, in Polish). Wyd. COBRD, Poznań.

\section{Copyrights}

Copyright for this article is retained by the author(s), with first publication rights granted to the journal.

This is an open-access article distributed under the terms and conditions of the Creative Commons Attribution license (http://creativecommons.org/licenses/by/3.0/). 